Polishchuk I.I., doct.sc.(econ.), assoc. prof., head at the marketing and advertising department, Dovhan Yu.V., cand.sc.(econ.), senior lecturer at the marketing and advertising department,

Korol I.V., student, Vinnytsia Institute of Trade and Economics of Kyiv National University of Trade and Economics

\title{
LOGISTICS AND MARKETING SUPPORT IMPROVEMENT IN THE EXPORT SUPPLY CHAIN
}

Поліщук I.I., д-р екон. наук, доцент, завідувач кафедри маркетингу та реклами,

Довгань Ю.В., канд. екон. наук, старший викладач кафедри маркетингу та реклами, Король І.B., студентка,

Вінницький торговельно-економічний інститут Київського національного торговельно-економічного університету

\section{УДОСКОНАЛЕННЯ ЛОГІСТИЧНОГО ТА МАРКЕТИНГОВОГО ЗАБЕЗПЕЧЕННЯ ЕКСПОРТНОГО ЛАНЦЮГА ПОСТАВОК}

Formulation of the problem. Favorable natural and climatic conditions of Ukraine, profitable logistics location of oil and fat Ukrainian companies and availability of the stable raw material base for production have provided opportunities for the formation of competitive advantages. These benefits are not entirely sustainable, as in most cases they involve cheap labor, low prices for oilseeds and products of its primary processing. Gained competitive advantages in the global oil and fat market, stable growing global demand and export orientation in the main segments of oil and fat products allow domestic companies to feel confident in the market. However, the global situation in the oil and fat market, consumer preferences and tastes in the world are changing dynamically and pose new challenges to companies that can be addressed by gaining more sustainable competitive advantages than those already gained due to the marketing- and logistics-oriented approaches to business activity.

In 2018, according to the World Bank's Logistics Performance Index, Ukraine ranked only $66^{\text {th }}$ among 160 countries surveyed in terms of logistics efficiency [1]. Insufficient level of development of the Ukrainian logistics infrastructure complicates the functioning of export logistics chains of oil and fat products and leads to an increase in its value.

Analysis of recent research and publications. Peculiarities of marketing supply chain management have been studied by such scientists as Budnik M., Kobets D., Keller K., Kutsenko V., Petrytska O., Petrovych Y., Khrabatyn O., Sviatnenko V., Starostina A., Stepanova Yu., Fedyshyn Yu., Yerokhin K., Chaplinskyi Yu., Yavorska L. and others. Scientists such as Dolishnii M., Zaburanna L., Krykavskyi Ye., Larina R., Frolova L., Khadzhynova O., Chumachenko O. and others have made a significant contribution to the development of theoretical and practical aspects of logistics support of Supply Chain Management (SCM). Despite a significant number of works on the issues of marketing and logistics of SCM, further research is needed to substantiate the areas of practical interaction of marketing and logistics support of the management of export supply chains of food products.

Setting objectives. The aim of the study is to identify the areas for improvement of logistics and marketing support in the oil and fat export supply chain.

Presentation of the main research material. Logistics and marketing are usually concerned with satisfying the customers' needs and wants, respectively through their supply and demand functions in a 
marketing channel. Logistics-marketing integration on the one hand, focuses on customer satisfaction emphasizing marketing activities concerning those related to product, price, promotion and distribution (place) supported by logistics. On the other hand, it provides acceptable level of profit by reducing logistic costs. Indeed, customer service has been recognized as "... the key link between logistics and marketing..." [2]. The logistics activity may be dependent on marketing activity in a marketing channel and the satisfaction of supply and the satisfaction of demand of customers' needs and wants have to be coordinated and synchronized in order to achieve customer value proposition in the global food market [3].

Fundamental reasons justifying the need for the integration process between logistics and marketing and supporting this process could be [4]:

- a growth of market differentiation (differentiation of customers' needs and preferences, individualization of market segments, products' diversification, etc.);

- growing competition in scope of the level and quality of services and customer service (a growth of demands in scope of additional benefits and usefulness connected with purchasing and sales of goods);

- a shorter product life-cycle;

- tendencies related to concentration in trade, creating and developing of new distribution channels; scale);

- integration of economic processes and decisive processes (using of synergy in micro- and macro

- a growth of new technology in the sphere of goods and information flow, promotion, sales, etc.;

- a growth of entrepreneurship and innovativeness and economic activities in the market;

- integration and globalization of markets.

Logistics and marketing are defined as the main orientations of management in a company and interpreted in the real sense as significant spheres of functional and integrated processes in a company. In a modern company marketing must be logistic, logistics must be a marketing one [5].

The global market for oil and fat products has changed significantly in recent decades. Key drivers of changes are a growing demand and innovative diversification of the approaches of oil and fat feedstock consumption in the food and other industries as well as its utilization as a new energy resource.

In the current conditions of the economic development and globalization, the Ukrainian oil and fat enterprises of the food industry face challenges related to the formation of effective marketing and logistics strategies in order to ensure competitiveness in the domestic and global markets.

Global volumes of production and consumption of oil and fat products have increased 1,8 times over the past thirty years from 80 million tons in the early $1990^{\text {th }}$ to 570 million tons in the late $2010^{\text {th }}$. In the structure of consumption of oil and fat products the largest share is occupied by the consumption of food products obtained on their basis, which on average for 2017-2019 amounted to 343,1 million tons or $62,1 \%$ of total consumption.

During 1998-2018, the price of vegetable oil and fats in food products obtained from them increased 1,7 times in the world market.

Due to the growth of consumption and prices, there can be observed a steady upward tendency towards the increase in the volumes of the world trade of oil and fat products reflecting the dynamics of changes in exports of vegetable oils (Tab. 1).

World export of vegetable edible oil (2001-2017), thousand tons

Table 1

\begin{tabular}{|c|c|c|c|c|c|c|c|}
\hline \multirow{2}{*}{ Type of oil } & \multicolumn{6}{|c|}{ Years } & \multirow{2}{*}{$\begin{array}{c}2017 \text { to } 2005 \\
\%\end{array}$} \\
\hline & 2001 & 2005 & 2010 & 2015 & 2016 & 2017 & \\
\hline Soybean oil & 8,811 & 10,358 & 10,910 & 12,727 & 13,067 & 12,104 & 116,8 \\
\hline Palm oil & $\mathrm{nd}^{*}$ & 23,930 & $n d^{*}$ & 47,519 & 42,465 & 46,929 & 196,1 \\
\hline Sunflower oil & 3,290 & 4,150 & 6,558 & 9,537 & 19,266 & 25,948 & 625,3 \\
\hline Rapes oil & 2,759 & 3,236 & 6,069 & $\mathrm{nd}^{*}$ & 7,576 & 7,209 & 222,8 \\
\hline
\end{tabular}

*nd - no data

Source: formed according to [6]

In Ukraine, oil and fat products are produced by more than 600 oil and fat enterprises. Oil and fat enterprises operate in all regions of Ukraine.

According to the results of 2018/2019 marketing year (MY), oil and fat enterprises of Ukraine produced 6,9 million tons of vegetable oils and fats. In 2019, 550 thousand tons of vegetable oils and fats were used for domestic food consumption in Ukraine.

About $95 \%$ of vegetable oils and fats produced in Ukraine are exported, and their value in 2018/2019 MY amounted to 4,7 billion US dollars. In 2019, revenues from exports of sunflower oil amounted to 4,1 billion US dollars; hence, the volume of exports in the soybean and rapeseed segments is growing, there appear new opportunities in the segments of high-oleic oilseeds, vegetable oils and fats and foods produced on their basis. 
Vegetable oils and fats produced in Ukraine are exported to more than 120 countries, among which the main ones are India $(30,6 \%)$, China $(15,7 \%)$, the Netherlands $(9,7 \%)$, Spain $(6,6 \%)$, Iraq and Italy $(5,6 \%$ each), Poland $(3,6 \%)$. These countries accumulate more than $77 \%$ in the total cost structure of exports of oil and fat products from Ukraine.

It should be noted that Ukraine has imports of vegetable oils and fats, which mainly meet the needs of the confectionery industry. The volume of imports in 2018/2019 MY amounted to 256 thousand tons, $90 \%$ of which was imported to Ukraine from Indonesia.

Agricultural oilseed producers, processing enterprises and intermediaries are the main elements of the export supply chain of oil and fat products in the trajectory of "production of raw materials - processing consumption" (Fig. 1).

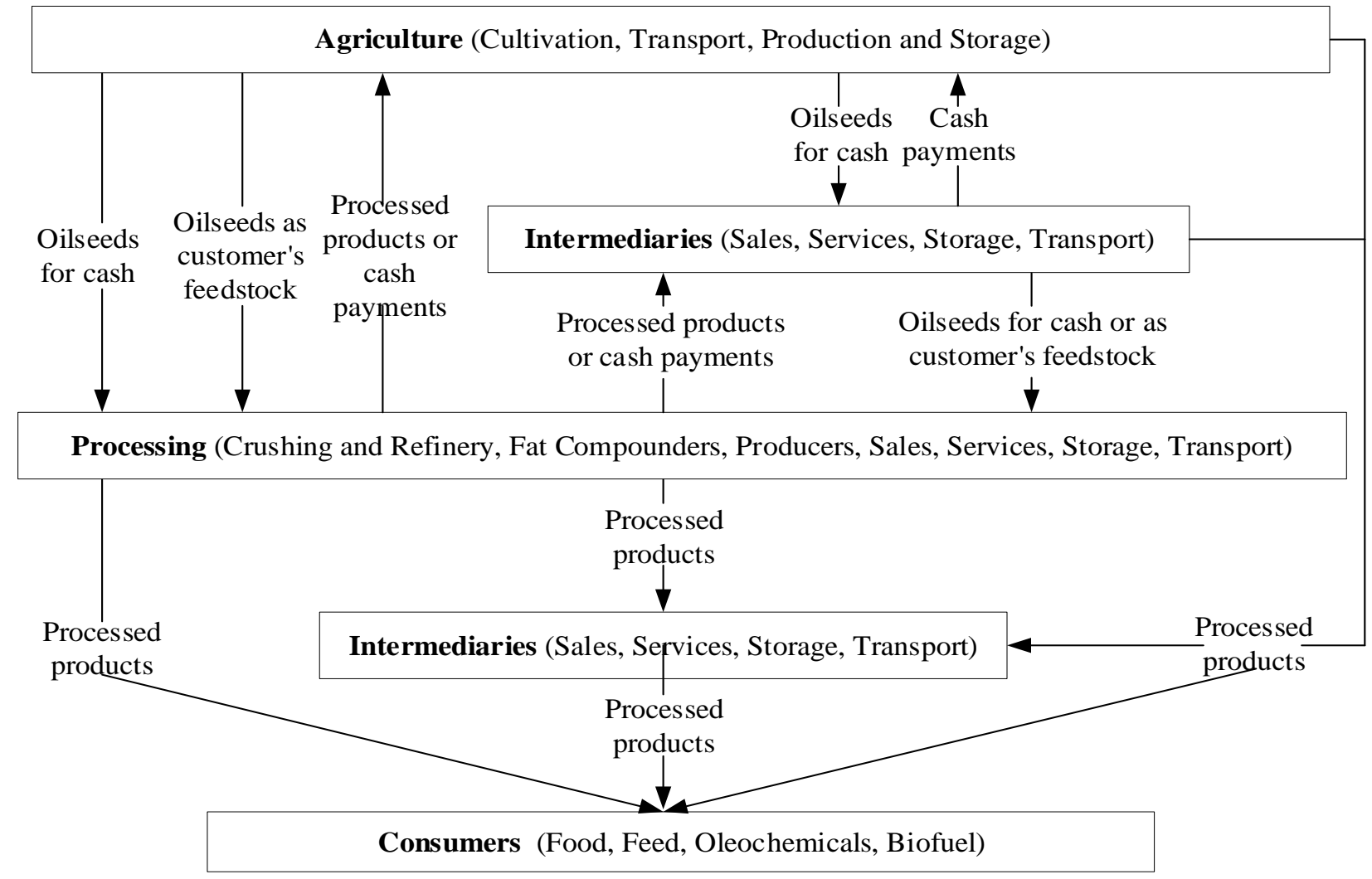

Fig. 1. Key elements of the supply chain of oil and fat products

Source: formed according to [7-9]

Subjects of oil and fat supply chains create their value for consumers, interact with each other and have a direct economic interest in the effective operation of these chains. Together with consumers, these business entities act as direct stakeholders in the supply chains of oil and fat products.

Efficiency of the supply chains of oil and fat products is complicated by the unregulated system of economic relations and imbalances, considering the interests of their main links.

The market for oil and fat products is a part of the overall food market. The marketing approach to the definition of the food market assumes that the market and commercial activities of the entities providing the supply should meet the needs of potential and actual consumers of agri-food products (or subjects of demand), i.e. be based on the marketing and logistics concepts.

One of the possible directions of effective consideration of the above-mentioned challenges is the logistization of the marketing activity of oil and fat enterprises of Ukraine's food industry and the use of integrated marketing logistics.

Typically, some managers think marketing logistics means only trucks \& warehouses. But in the present time, logistics is much more than previous. Marketing logistics is also known as physical distribution. It involves:

- planning;

- implementing;

- controlling the physical flow of goods;

- relevant information from points of origin to point of consumption;

- meeting customer requirements for a profit.

Marketing management of logistics activity performs general management functions that are market 
and consumer oriented. These functions include analysis, planning, organization, motivation, and control.

Logistics and marketing are complementary - logistics satisfies demand stimulated by marketing. Simultaneousness of being and correlation of marketing-mix instruments bring about that distribution must be adjusted to other instruments and change with them [4]. The tools of marketing-mix such as product, pricing, distribution and logistics-mix as product, quantity, condition, time, place, customer, costs are used to perform management functions. These tools are combined by the marketing and logistics information systems and researches. Integration of logistics and marketing tools provides greater value to customers.

According to research carried out by the consulting company "Pittigloi Rabin Todd \& McGrath", evaluation, analysis and timely planning of logistics costs can increase turnover by $40-60 \%$, increase productivity by $44 \%$, reduce total logistics costs by $3-4 \%$, reduce total costs for creation of stocks by $50 \%$ and reduce contract execution terms by $30-40 \%$ [6]. Poor integration between logistics and marketing support can impact oil and fat company's performance in terms of transit times, level of loss, transport and packaging costs.

The export supply chain of oil and fat products includes economic interests of business entities that develop varieties of oil and fat seeds, machinery and technology, supply of resources, production of raw materials, processing, storage and transportation, etc. A key position in the supply chain is occupied by the consumer. The success of the marketing and logistics strategies of the enterprise depends on the degree of consideration of the interests of the stakeholders of supply chain of oil and fat products and the individuals, communities, society and the state.

High concentration of the market of vegetable edible oils provides its main entities (multinational companies) with significant competitive advantages over small and medium-sized market participants, namely: access to investment capital, innovative technologies and developed logistics infrastructure. In the global sunflower oil market, the main players are four large companies, namely Cargill, Bunge, Archer Daniels Midland Company, Louis Dreyfus Commodities and only two producer countries (Ukraine and the Russian Federation), which provide about $60 \%$ of the world exports.

An important element of the supply chain of oil and fat products and creation of the added value is storage and transportation. Small and medium-sized producers do not have their own significant capacity for storage, primary processing of raw materials and production of oil and fat products, and therefore they transport and store them in the elevators of grain traders or processing companies. High transportation and storage tariffs force producers to sell raw materials and products in the early stages of the logistics chain.

As it has been mentioned above, the demand for vegetable edible oils is growing in the world. Ukraine is a traditional world leader in the production of sunflower oil. Ukraine's share in the world production of sunflower oil is $55,1 \%$, among which $99,2 \%$ is exported to the Middle East, Asia and the EU. Ukrainian unrefined sunflower oil in bulk, which is used by importing countries as raw material for further processing, is especially popular. (Fig. 2).

A typical logistics chain of export of Ukrainian vegetable edible oils consists of four main elements

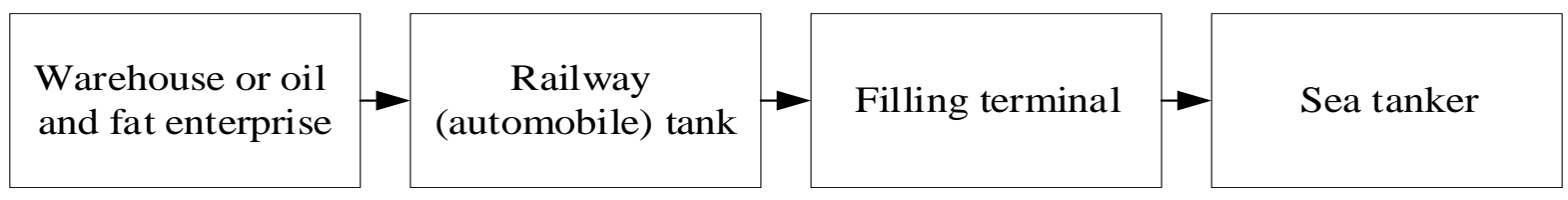

OR

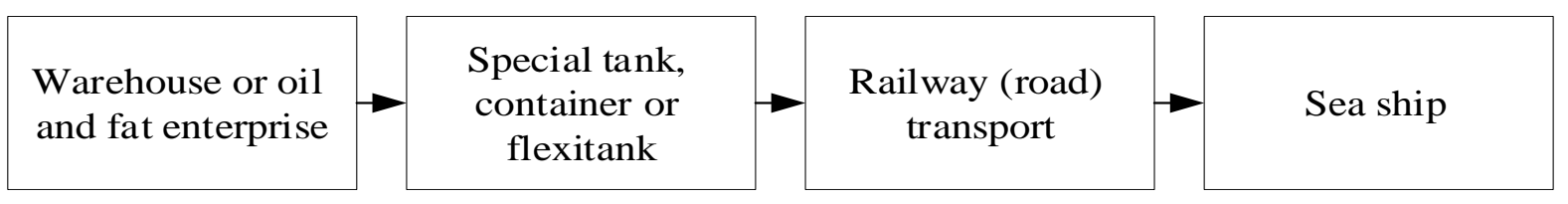

Fig. 2. Typical logistics schemes for the export of vegetable edible oils

Source: author's development

At the first stage, oil is shipped from the warehouse or oil and fat plant in automobile (railway) tanks or specialized tanks. At the second stage, the cargo is delivered to the seaport, then it is transshipped to a seagoing vessel or sea tanker, which delivers oil to the destination country.

Delivery of vegetable oil for export from the producer to the seaport is carried out by automobile or railway tanks in bulk or in special tanks. In terms of transportation costs, this type of transportation of vegetable oil is one of the most efficient and economical. The choice of vehicle depends on the amount of vegetable oil to be transported, location of the manufacturer, and the transport interchange of the supplier. In 1990-2000, the delivery of sunflower oil to ports was carried out exclusively by railway transport, but in the following years, due to the increase in its exports, truckers were actively involved in the delivery. Today, about $40 \%$ of sunflower oil is delivered to ports by road. 
Recently, the transportation of sunflower oil in flexitanks has become widespread. A flexitank is a flexible container used for transportation and storage of liquid, food, bulk, as well as bulk dangerous goods for industrial use. The material of the container does not interact with the cargo even during prolonged transportation and high temperatures. Transportation of sunflower oil in flexitanks has a number of advantages in comparison with other methods of delivery, in particular [10]:

- the cargo does not require pre-packaging, for example in barrels, canisters or other containers for bulk cargo;

- when transported in flexitanks, the volume of cargo can be increased by $30 \%$ compared to the transportation of packaged goods;

- transportation is carried out at the rate of a 20 -foot dry cargo container, not a tank container, which saves about 500 and 1000 US dollars per container;

- the consignor or consignee is exempt from the costs of returning and cleaning the equipment, for example, as in the case of transportation in tanks, i.e. only the cost of delivery of the goods is paid.

A promising direction of the reduction of logistics costs in the export of Ukrainian vegetable oils is the use of river transport that is cheaper than the motor transport and faster than railway transport (Fig. 3).

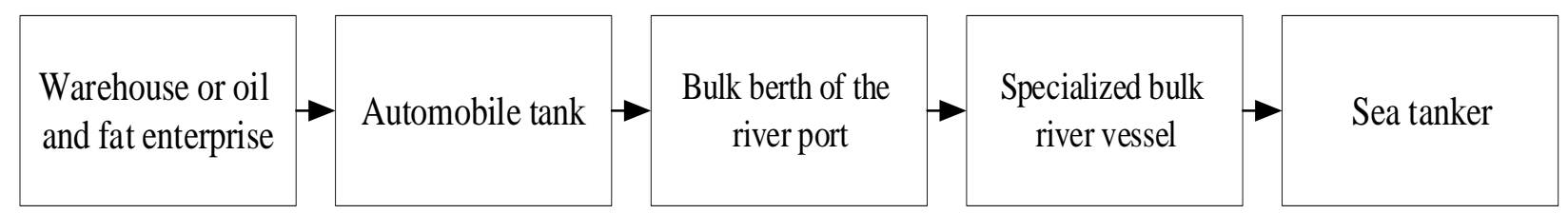

Fig. 3. Scheme of the logistics chain of export of vegetable edible oils using river transport

Source: author's development

In 2019, for the first time in Ukraine, the export transportation of vegetable edible oils using the technology of transshipment "river board - sea board", which had not been previously used for this type of cargo, were started.

The development of river transport and infrastructure requires significant investments that can be used by oil and fat enterprises. However, the issues of regulatory and legal support of river transport in Ukraine remain unresolved.

In our opinion, state support for the creation of export-oriented logistics infrastructure projects is a necessary element for improving the logistics efficiency of the supply chain of oil and fat enterprises in Ukraine, as logistics restrictions often constrain the growth rate of exports. In addition to the obvious minimization of export logistics costs of oil and fat enterprises, additional benefits of using river transport may become unloaded roads, reduced fuel consumption and environmental pollution.

Conclusions from the study. Current trends towards the increase in the global demand for vegetable oil and fats on the market require from the domestic enterprises of the oil and fat subcomplex the adjustment of their individual marketing and logistics strategies. Based on the actual and predicted data on the development of the oil and fat market, it should be taken into account that from year to year the world's consumption of oil per capita increases; more consumers prefer natural edible oils of vegetable origin; palm oil is the main competitor for Ukrainian players in the world market; Ukraine has a powerful natural, productive and logistics potential for increasing the export supply of vegetable edible oil and fat.

Formation of sustainable competitive advantages of oil and fat companies in the global supply chains is possible through the development of marketing-mix that will include marketing and logistics components. The most effective results for the enterprise are provided by the use of marketing management and logistics concepts that are oriented at identifying and meeting consumer demand as well as consideration of the interests of all other stakeholders in the supply chain of oil and fat products, the individual, community and society, i.e. modern concept of integrated marketing logistics.

\section{Literature}

1. Logistics Performance Index. URL: https://lpi.worldbank.org/international/aggregated-ranking (дата звернення: 20.06.2021).

2. Coyle J. J., Bardi E. J., Langley C. J. The management of business logistics: a supply chain perspective. 7th ed. Mason. Ohio : South-Western/Thomson Learning, 2003. 707 p.

3. Madhani P. M. Logistics and Marketing Integration: Enhancing Competitive Advantages. The IUP Journal of Management Research. 2017. Vol. XVI. № 3. P. 7-30.

4. Pilarczyk B., Mruk H., Sojkin B., Szulce H. Podstawy marketingu. Poznan : Wydawnictwo Akademii Ekonomicznej, 1999. 349 p.

5. Kotler P. Marketing management: analysis, planning, implementation, and control. 7th ed. Englewood Cliffs : Prentice-Hall International Editions, 1991. 756 p. 
6. Pittiglio Rabin Todd \& Mcgrath. URL: http://www.whereorg.com/pittiglio-rabin-todd-mcgrath (дата звернення: 20.06.2021).

7. Gonchar O., Zamkova N., Polishchuk I., Dovhan Yu., Sokolovska V. Oil and Fat Business of Ukraine: Marketing Orientation for Achieving Competitive Advantages. European Journal of Sustainable Development. 2020. Vol. 9. № 4. P. 261-272. DOI: 10.14207/ejsd.2020.v9n4p261

8. Поліщук І.І., Довгань Ю.В. Маркетингові аспекти управління олійно-жировими підприємствами. Вісник Херсонського національного технічного університету. 2020. № 2(73). С. 93100. DOI: $10.35546 / \mathrm{kntu2078-4481.2020.2.12}$

9. Довгань Ю.В. Формування маркетингової стратегії просування інноваційних рослинних харчових олій. Економіка та держава. 2020. № 1. C. 126-131. DOI: 10.32702/2306-6806.2020.1.126

10. Качество и безопасность транспортировки растительных масел. URL: https://www.apkinform.com/ru/exclusive/topic/1023856\#.VQ6Y89zGC3w (дата звернення: 20.06.2021).

\section{References}

1. Logistics Performance Index, available at: https://lpi.worldbank.org/international/aggregated-ranking (access date June 20, 2021).

2. Coyle, J.J, Bardi, E.J. and Langley, C.J. (2003), The management of business logistics : a supply chain perspective, 7th ed., South-Western/Thomson Learning, Mason, Ohio, USA, 707 p.

3. Madhani, P.M. (2017), "Logistics and Marketing Integration: Enhancing Competitive Advantages", The IUP Journal of Management Research, Vol. XVI, no. 3, pp. 7-30.

4. Pilarczyk, B., Mruk, H., Sojkin, B. and Szulce, H. (1999), Podstawy marketingu, Wydawnictwo Akademii Ekonomicznej, Poznań, Poland, 349 p.

5. Kotler, P. (1991), Marketing management: analysis, planning, implementation, and control, 7th ed., Prentice-Hall International Editions, Englewood Cliffs, USA, 756 p.

6. Pittiglio Rabin Todd \& Mcgrath, available at: http://www.whereorg.com/pittiglio-rabin-todd-mcgrath (access date June 20, 2021).

7. Gonchar, O., Zamkova, N., Polishchuk, I., Dovhan, Yu. and Sokolovska, V. (2020), "Oil and Fat Business of Ukraine: Marketing Orientation for Achieving Competitive Advantages", European Journal of Sustainable Development, Vol. 9, no. 4, pp. 261-272, DOI: 10.14207/ejsd.2020.v9n4p261

8. Polishchuk, I.I. and Dovhan, Yu.V. (2020), "Marketing aspects of management of oil and fat enterprises", Visnyk Khersonskoho natsionalnoho tekhnichnoho universytetu, no. 2(73), pp. 93-100, DOI: 10.35546/kntu2078-4481.2020.2.12

9. Dovhan, Yu.V. (2020), "Formation of marketing strategy for the promotion of innovative vegetable edible oils", Ekonomika ta derzhava, no. 1, pp. 126-131, DOI: 10.32702/2306-6806.2020.1.126

10. "Quality and Safety of Vegetable Oil Transportation", available at: https://www.apkinform.com/ru/exclusive/topic/1023856\#.VQ6Y89zGC3w (access date June 20, 2021). 